\title{
Digestive enzyme activity as a quantitative measure of protistan grazing: the acid lysozyme assay for bacterivory
}

\author{
Juan M. González*, Barry F. Sherr, Evelyn B. Sherr \\ College of Oceanic and Atmospheric Sciences, Oregon State University, Oceanogr. Admin. B-104, Corvallis, \\ Oregon 97331-5503, USA
}

\begin{abstract}
We propose quantification of the activity of digestive enzymes as a novel way to estimate rates of protist grazing in natural waters. Our first application of this approach was determination of protistan bacterivory by assaying the activity of lysozyme at acid $\mathrm{pH}$. Lysozyme specifically degrades peptidoglycan, a major structural component of prokaryotic cell walls. The basis of the method is determination of lysozyme activity present in protistan food vacuoles by using a fluorochrome-linked artificial substrate, 4 -methylumbelliferyl $\beta-D-N, N^{\prime}, N^{\prime \prime}$-triacetylchitotriose (MUF-[GlcNAc) 3 ) as an andlogue of peptidoglycan. Measurement of rate of MUF cleavage from the substrate in sonicated samples at acid $\mathrm{pH}$ (4.5) distinguishes activity of digestive enzymes present in protistan food vacuoles from extracellular or intracytoplasmic lysozyme activity. Acid lysozyme activity was calibrated against rate of bacterivory estimated using the fluorescently labeled bacteria (FLB) uptake method. Results from the 2 methods were significantly correlated $\left(r^{2}=0.98\right)$ for both cultures of bacterivorous protists and for estuarine and nearshore seawater samples, over a wide range of rates of bacterivory $\left(10^{3}\right.$ to $10^{6}$ bacteria $\mathrm{ml}^{-1} \mathrm{~h}^{-1}$ ). The relation between the 2 variables determined from water samples taken in open North Pacific gyre water had a higher slope compared to that of the other samples. The advantages of the acid lysozyme activity method are that it does not require in vivo incubations, manipulation of live samples, or microscopy, as do other current methods of estimating bacterivory, and that a large number of discrete samples can be quickly processed. Separate calibration of the assay, using alternate measures of bacterivory, is recommended for individual applications.
\end{abstract}

\section{INTRODUCTION}

Bacteria and their protistan grazers are of major importance to the functioning of pelagic foodwebs and biogeochemical cycles (Pomeroy 1974, Azam et al. 1983). A large fraction of phytoplankton production (20 to $50 \%$ ) is channeled through bacteria (Azam et al. 1983, Cole et al. 1988). Determining the fate of bacterial production in pelagic ecosystems is consequently fundamental to understanding how such systems function.

Phagotrophic protists, including flagellates and ciliates, are the dominant bacterivores in most aquatic ecosystems (Azam et al. 1983, McManus \& Fuhrman

- Present address: Japan Marine Science and Technology Center (JAMSTEC), 2-15 Natsushima-cho, Yokosuka 237 , Japan
1988, Pace 1988, Sherr et al. 1989). Various methods have been used to estimate in situ bacterivory. Some techniques rely on following changes in bacterial numbers during long-term incubations (12 to $48 \mathrm{~h}$ ) after manipulations, e.g. size-fractionation or dilution of water samples, or addition of metabolic inhibitors, to reduce or eliminate protistan grazing (e.g. Landry et al. 1984, Wright \& Coffin 1984, Sherr et al. 1986). Another approach has been to quantify protistan ingestion of labeled analogues of bacterioplankton, either bacterial-sized fluorescent microspheres, fluorescently labeled bacteria (FLB), or radiolabeled bacterial cells (Wikner et al. 1986, Nygaard \& Hessen 1990). Labeled bacterial analogues have been used in short-term uptake assays (e.g. Sherr et al. 1987, 1989) or long-term disappearance experiments (e.g. Nygaard \& Hessen 1990, Marrasé et al. 1992). 
There are problems associated with each of these approaches: significant changes in the original microbial assemblage during long-term incubations (Ferguson et al. 1984), experimental artifacts due to manipulation (Ferguson et al. 1984, Taylor \& Pace 1987), and discriminatory feeding on added bacterial analogues (Pace \& Bailiff 1987, Sherr et al. 1987, 1989, González et al. 1990a, Simek \& Chrzanowski 1990). Radiolabeled prey tracer experiments have additional problems due to difficulties in separation of labeled predator from labeled prey biomass. Short-term uptake of FLB by natural assemblages of protists is, at present, a commonly used technique for estimating in situ bacterivory (e.g. Bloem. et al. 1989, Sherr et al. 1989, Epstein \& Shiaris 1992, Simek \& Straskrabova 1992).

Here we propose the acid lysozyme ( $\left.\mathrm{L}_{\mathrm{ACID}}\right)$ assay for estimating protistan bacterivory in natural waters. The $\mathrm{L}_{\mathrm{ACID}}$ assay is based on quantification of lysozyme activity in cell lysates at acid $\mathrm{pH}$, and does not require in vivo incubation of microbes. Lysozyme is an enzyme which specifically degrades bacterial cell walls by breaking the $\beta(1-4)$ linkage between residues of $\mathrm{N}$-acetylmuramic acid and N-acetylglucosamine in the structural polymer, peptidoglycan (Stryer 1981). Peptidoglycan occurs only in the cell walls of eubacteria. Yang \& Hamaguchi (1980) proposed a sensitive assay for measuring lysozyme activity by using a fluorogenic substrate, 4 -methylumbelliferyl $\beta-D-N, N^{\prime}, N^{\prime \prime}$-triacetylchitotriose (MUF-[GlcNAC] $]_{3}$, whose reaction product, 4-methylumbelliferone $[\mathrm{MUF}$ ), is highly fluorescent. MUF does not fluoresce when bound to the substrate, thus increase in MUF fluorescence is an indication of enzymatic cleavage of the fluorochrome from the substrate. In phagotrophic protists, food vacuole $\mathrm{pH}$ is 3 to 5 during the digestion process (Nilsson 1979, Sleigh 1989); several authors have reported that protistan digestive enzymes have maximal activity at acid pH (Müller et al. 1966, Nilsson 1979, Nagata \& Kirchman, 1992). In contrast, marine bacterial exoenzymes have highest activities at the basic pH of seawater (Münster 1991) and are inactive at $\mathrm{pH}<5$ (Nagata \& Kirchman 1992). Thus, rate of production of MUF from MUF-[GIcNAc] 3 at acid pH ( $\mathrm{L}_{\mathrm{ACI}}$ activity) should be a specific indicator of protistan bacterivory.

The acid lysozyme assay is the first application of a new approach to estimating protistan grazing in situ, i.e. relating the activity of digestive enzymes in protist food vacuoles at the time of sampling to rates of prey consumption.

\section{MATERIALS AND METHODS}

Sampling sites. Samples of surface seawater were collected using 51 Niskin bottles from the mouth of
Coos Bay, Oregon, USA $\left(43^{\circ} 21^{\prime} \mathrm{N}, 124^{\circ} 20^{\prime} \mathrm{W}\right)$ at high tide, and from 2 stations during a cruise of the Oregon coast in August 1992. The 2 stations at sea, nearshore (NS-1) and offshore (OS-1), were located in the Pacific Ocean at $42^{\circ} 40^{\prime} \mathrm{N}, 125^{\circ} 28^{\prime} \mathrm{W}$ and $44^{\circ} 33^{\prime} \mathrm{N}, 124^{\circ} 15^{\prime} \mathrm{W}, 56$ and $380 \mathrm{~km}$ from shore, respectively.

Cultures. Species of bacterivorous protists were isolated from Pacific coastal waters and maintained in $0.2 \mu \mathrm{m}$ filtered seawater with boiled wheat grain at $15^{\circ} \mathrm{C}$ in the dark. The flagellate isolates used in this study were designated E1, E4, and B3 from Yaquina Bay, Oregon, and E9 from Catalina Island, California, USA. E1 was a 4 to $7 \mu \mathrm{m}$ bodonid. E4 was identified as Cafeteria sp. E9 was a 3 to $5 \mu \mathrm{m}$ monad with 2 equal flagella; $\mathrm{B} 3$ was a 2 to $5 \mu \mathrm{m}$ monad with 1 short and 1 long flagellum. Cultures of the marine flagellates Bodo parvulus and Paraphysomonas sp., provided by David Caron, were also used. A scuticociliate, Uronema sp., was isolated from Coos Bay.

Phytoplankton species of diverse taxa - a coccoid cyanobacterium, Synechococcus sp.; 2 prasinophytes, Pycnococcus provasoliz and Micromonas pulsilla; a chrysophyte, Pelagococcus subviridis; and a diatom, Thalassiosira pseudonana, provided by Dr Lynda Shapiro - were used for control tests of possible $\mathrm{L}_{\mathrm{ACID}}$ activity in phytoplankton, as well as of potential for high background fluorescence due to chlorophyll and accessory pigments. Phytoplankton cultures were grown in f/2 medium (Harrison et al. 1980) under natural light at room temperature. Mixed species bacterial assemblages, grown up on $1 \mathrm{mg} \mathrm{l}^{-1}$ yeast extract added to $0.6 \mu \mathrm{m}$ filtered coastal seawater, were used for preparation of FLB.

Acid lysozyme ( $\mathrm{L}_{\mathrm{AC} \text { DD }}$ ) assay. 4-Methylumbelliferyl $\beta-D-N, N^{\prime}, N^{\prime \prime}$-triacety]chitotriose (MUF-[GlcNAc] $]_{3}$ ) (Sigma Co.) (Yang \& Hamaguchi 1980) was dissolved in Methylcellosolve (ethylene glycol monomethyl ether) (Hoppe 1983) to yield a concentration of $5 \mathrm{mM}$. Dilutions of the substrate stock solution were made in $0.2 \mu \mathrm{m}$ filtered, deionized water. Samples of protist cultures or of seawater were sonicated with a W185 Sonifier Cell Disrupter with tapered microtip (HeatSystems-Ultrasonics, Inc.) at $50 \mathrm{~W}$ for two $10 \mathrm{~s}$ bursts. Two types of controls were prepared: boiled controls prepared by incubating sonicated subsamples for $8 \mathrm{~min}$ in boiling water, and filtered controls prepared by gently filtering unsonicated subsamples through $0.2 \mu \mathrm{m}$ Acrodiscs

Reactions were performed in capped $20 \mathrm{ml}$ glass scintillation vials or $15 \mathrm{ml}$ teflon vials; triplicate vials were prepared for both experimental samples and controls. $1.8 \mathrm{ml}$ of acetate buffer $(\mathrm{pH} 4.5,0.05 \mathrm{M})$ and $0.4 \mathrm{ml}$ of substrate solution ( $5 \mu \mathrm{M}$ final concentration) were added to $1.8 \mathrm{ml}$ of sonicated sample in each vial. 
The preparations were incubated in the dark at the original temperature of the sample or culture for 4 to $48 \mathrm{~h}$, depending on the intensity of enzyme activity. Since temperature is a major parameter affecting metabolic processes, it is vital that $\mathrm{L}_{\mathrm{ACID}}$ assays as well as other measures of bacterivory, e.g. FLB uptake, be carried out at the temperature at which the protists are growing, in order to assess rates of bacterivory at that temperature.

The enzymatic reaction was stopped by adding $2 \mathrm{ml}$ of glycine-ammonium hydroxide buffer ( $\mathrm{pH} 10.3$, $0.05 \mathrm{M}$ glycine in $\left.0.2 \mathrm{M} \mathrm{NH}_{4} \mathrm{OH}\right)$. MUF fluoresces most intensely at basic pH (Hoppe 1983, Chróst 1991). Fluorescence intensity was measured with a Turner 110 Fluorometer equipped with a $365 \mathrm{~nm}$ excitation filter and a $>450 \mathrm{~nm}$ emission filter. Fluorescence was converted to concentration of MUF using a standard curve prepared from dilutions of a $5 \mathrm{mmol} \mathrm{l}^{-1}(\mathrm{mM})$ MUF (Sigma Co.) stock solution, over the concentration range of 0.1 to $10 \mathrm{nmol}^{-1}$ (nM) MUF.

Determining optimum $\mathbf{p H}$ : The $\mathrm{L}_{\mathrm{ACID}}$ assay was carried out over a range of acid $\mathrm{pH}$ values, from 3 to 5.5, using either glycine- $\mathrm{HCl}$ buffer ( $\mathrm{pH}$ from 3.0 to 3.6 ) or acetate buffer ( $\mathrm{pH}$ from 3.5 to 5.5 ) as the incubation buffer solution. Flagellate cultures, bacterial cultures obtained from $0.6 \mu \mathrm{m}$ filtered flagellate cultures, and natural bacterial assemblages in $0.6 \mu \mathrm{m}$ filtered seawater samples grown with yeast extract were tested in these experiments. Assays were also carried out at higher $\mathrm{pH}$ (6 to 8 ) using cultures of bacterivorous flagellates.

Determining optimum sonication time: The amount of sonication necessary for maximum rate of $\mathrm{L}_{\mathrm{AcID}}$ activity was determined by quantifying fluorescence yield versus the number of $10 \mathrm{~s}$ sonication bursts $(50 \mathrm{~W})$ for triplicate subsamples of flagellate culture.

Linearity of MUF production over time: The reaction in triplicate enzyme activity assays using a mixed flagellate culture (Cafeteria sp. and B3 flagellates) was stopped at various times from 2 to $72 \mathrm{~h}$, and fluorescence intensity was measured as described above.

Stability of MUF in the reaction solution: The stability of MUF fluorescence during incubation was tested by adding a known concentration of MUF to reaction mixtures containing sonicated samples and acetate buffer. Glycine- $\mathrm{NH}_{4} \mathrm{OH}$ buffer was added to some replicates immediately and to others after $48 \mathrm{~h}$ of incubation. The stability of MUF after stopping the enzymatic reaction was also tested by comparing fluorescence intensity of samples just after the addition of glycine- $\mathrm{NH}_{4} \mathrm{OH}$ buffer and after $48 \mathrm{~h}$ of incubation at room temperature in the dark.

Concentration of nanoplankton to improve method sensitivity: Aliquots of seawater samples collected in Coos Bay and at the nearshore and offshore sampling stations were concentrated by centrifugation in order to test whether a higher fluorescence yield could be obtained compared to unconcentrated samples. Samples were centrifuged at $2000 \times g$ for $15 \mathrm{~min}$. Based on prior tests in the laboratory using cultured flagellates, this procedure yielded the highest percent recovery of bacterivorous flagellates.

FLB uptake experiments. Results from the acid lysozyme activity assay were compared to a direct measure of bacterial uptake rates, by linear regression of rates of MUF production (pmol MUF ml-1 sample $\mathrm{h}^{-1}$ ) and rates of bacterivory by the protist community (bacteria ingested $\mathrm{ml}^{-1}$ sample $\mathrm{h}^{-1}$ ), as determined from rate of uptake of FLB. FLB were prepared from mixed species assemblages of coastal bacterioplankton, stained with 5-([4,6-dichlorotriazin-2-yl]amino) fluorescein (DTAF) at $60^{\circ} \mathrm{C}$ for $2 \mathrm{~h}$, as described by Sherr et al. (1987).

All FLB uptake experiments were carried out in $400 \mathrm{ml}$ Whirl Pak bags presoaked in 10\% (vol/vol) $\mathrm{HCl}$ and copiously rinsed with deionized water (Sherr et al. 1987). Experiments were run in the dark at the original temperature of the sample. Uptake experiments were run in duplicate at the same time as the enzyme assay was performed. Final concentrations of FLB were 5 to $10 \%$ of the in vivo bacterial density. Aliquots of $5 \mathrm{ml}$ for cultures and $20 \mathrm{ml}$ for natural assemblages were taken at several times during a $2 \mathrm{~h}$ period after FLB addition, and fixed by the LugolFormalin decoloration technique (Sherr et al. 1992). Per-cell clearance rates ( $\mathrm{nl}$ cell ${ }^{-1} \mathrm{~h}^{-1}$ ) were calculated by dividing the cell-specific uptake rates of FLB by the concentration of FLB per nl (Sherr et al. 1987). Rates of community clearance of bacteria were calculated by multiplying the per-cell clearance rates by the total abundance of bacteria per $\mathrm{ml}$ and by the abundance of bacterivorous protists in the samples (Sherr et al. 1987). A minimum of 200 protists were inspected per slide.

Enumeration procedures. Bacterial abundance was estimated by the acridine orange direct count method (Hobbie et al. 1977). Protists were enumerated by DAPI staining according to Porter \& Feig (1980) as modified by Sherr et al. (1987). FLB were counted on unstained $0.2 \mu \mathrm{m}$ polycarbonate filters. FLB in flagellate food vacuoles were visualized in DAPI stained preparations as described by Sherr et al. (1987). Average bacterioplankton cell volumes in nearshore and offshore waters were estimated from measurement of $>200$ cells from each sample site in micrographs projected onto a screen.

Statistical analysis. Statistics were performed as described by Sokal \& Rohlf (1981). The F-test was used to estimate significant differences between regression coefficients. 


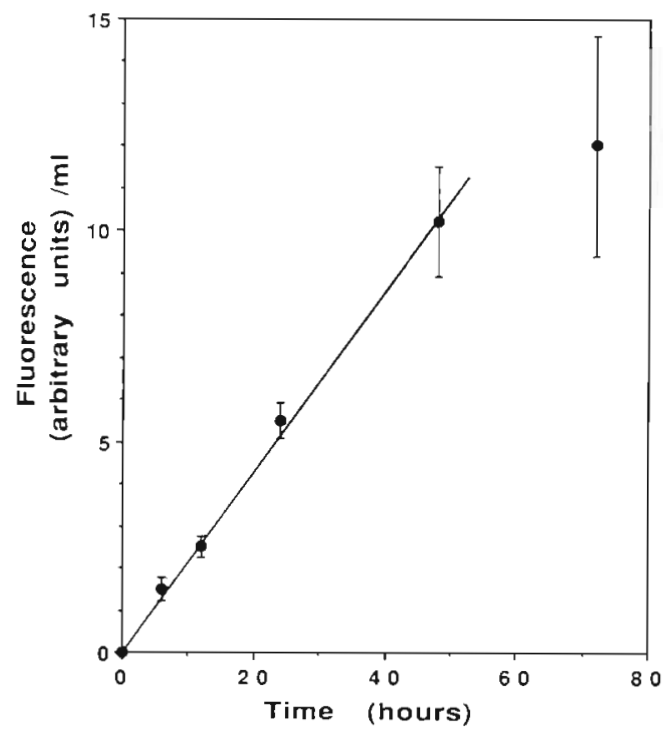

Fig. 1. Linear production of MUF fluorescence (relative intensity units) over time, obtained by stopping enzymatic reactions at various times up to $48 \mathrm{~h}$. Samples were prepared from a sonicated culture of mixed bacterivorous flagellates

\section{RESULTS}

\section{MUF substrate}

Initial tests of rate of MUF production versus MUF$[\mathrm{GlcNAc}]_{3}$ concentration, using cultures of bacterivorous protists, showed saturation of enzyme activity at $5 \mu \mathrm{M}$ of substrate. In this study, maximum MUF

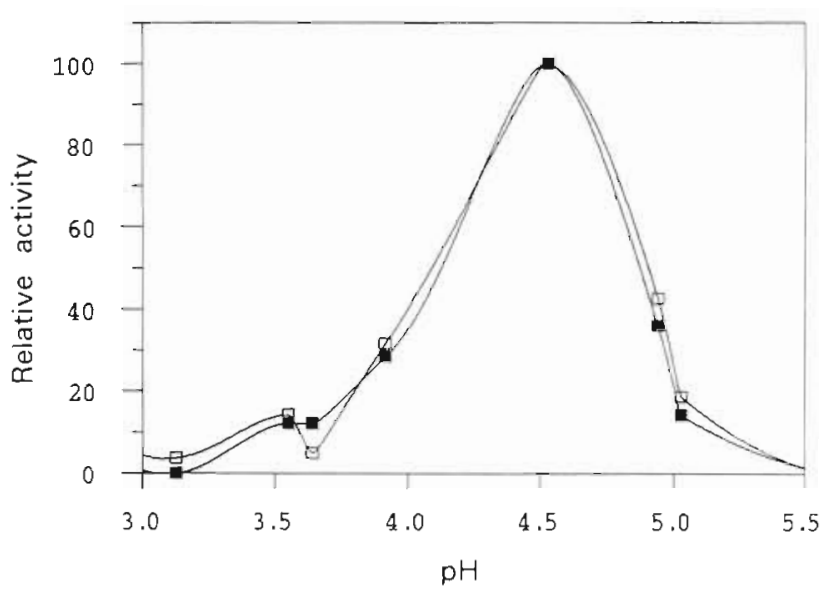

Fig. 2. Relative activity of lysozyme in sonicated samples of bacterivorous protists, for acid lysozyme activity assays carried out at $\mathrm{pH}$ between 3.0 and 5.5. (-) Culture of the E9 flagellate; $\square$ mixed species assemblage of bacterivorous flagellates grown up from a sample of coastal seawater production was 100 -fold lower than the amount expected from complete cleavage of MUF from $5 \mu \mathrm{M}$ of substrate. Enzyme-mediated product formation showed a linear increase over time up to $48 \mathrm{~h}$ (Fig. 1). Thus, $5 \mu \mathrm{M}$ of MUF-[GICNAc] 3 appeared to be saturating during our assays, which were all $<48 \mathrm{~h}$ duration.

A MUF standard curve was used to relate fluorescence intensity $(F I)$ to MUF concentration (MUF); using the $10 \times$ window of the fluorometer, the regression equation of $F I$ versus $M U F$ (nM) was $F I=-2.95+$ 22.7 MUF, $\mathrm{r}^{2}=0.97$. Tests showed that MUF fluorescence was stable both during the experiments and after the enzymatic reaction was stopped by raising the $\mathrm{pH}$ to 10.3 . This agrees with findings by other authors who have used fluorochrome-linked substrates to investigate activity of exoenzymes in natural waters (Hoppe 1983, Somville 1984). The minimum detection limit using the $10 \times$ window was $0.17 \mathrm{nM}$ (nmol I-1, or pmol ml-1) of MUF. $\mathrm{L}_{\mathrm{ACID}}$ activity was in the range of 0.003 to $0.6 \mathrm{pmol}$ of MUF produced per ml of sample tested per hour.

\section{Lysozyme activity as a function of $\mathrm{pH}$}

A peak of lysozyme activity was found at $\mathrm{pH} 4.5$ in samples containing bacterivorous protists (Fig. 2). Samples containing only bacteria $(0.6 \mu \mathrm{m}$ filtrates from cultures and natural assemblages) did not show detectable fluorescence intensities at $\mathrm{pH}<5.5$, although peaks of activity at $\mathrm{pH}$ values of 7 and 8.4 indicated the presence of intracellular and/or extracellular lysozymes (data not shown). Other authors have also reported maximal activity of digestive enzymes in protists in the pH range of 4 to 5 (Nilsson 1979, Nagata \& Kirchman 1992).

We also tested for the production by phytoplankton cultures of compounds that might fluoresce at the wavelength characteristic of MUF, and did not find any such contaminating fluorescence in samples without added MUF substrate.

Synechococcus sp., Pycnococcus provasolii, Thalassiosira pseudonana and Pelagococcus subviridis did not hydrolyze the MUF substrate at abundances of up to $10^{6}$ phytoplankton cells $\mathrm{ml}^{-1}$. However, the $2 \mu \mathrm{m}$ prasinophyte, Micromonas pusilla, showed a high rate of $L_{A C I D}$ activity (Table 1). FLB uptake experiments revealed that $M$. pusilla was in fact ingesting bacteria. To our knowledge, this is the first report of mixotrophy in this species of phytoplankton. Although bacterial suspensions did not show MUF production, concentrations of yeast extract $>0.1 \%$ in bacterial culture media resulted in a high background fluorescence in the absence of substrate. 
Table 1 Results of all experiments in which acid lysozyme activity ( $\mathrm{pmol}$ MUF $\mathrm{ml}^{-1}$ sample $\mathrm{h}^{-1}$ ) was compared to bacterivory (bacteria $\mathrm{ml}^{-1}$ sample $\mathrm{h}^{-1}$ ), estimated by combining short-term per cell uptake of fluorescently labeled bacteria with abundance of phagotrophic protists and total standing stock of bacteria. Values are averages of triplicate assays \pm 1 SD

\begin{tabular}{|c|c|c|c|}
\hline Sample & $\begin{array}{l}\text { Phagotrophic protists } \\
\text { (cells ml-1) }\end{array}$ & $\begin{array}{l}\text { Acid lysozyme activity } \\
\left(\text { pmol ml-1 } \mathrm{h}^{-1}\right)\end{array}$ & $\begin{array}{c}\text { Bacterivory } \\
\left(10^{4} \text { bacteria } \mathrm{ml}^{-1} \mathrm{~h}^{-1}\right)\end{array}$ \\
\hline Paraphysomonas sp. & $1.5 \times 10^{4}$ & $0.290 \pm 0.040$ & $4.15 \pm 0.30$ \\
\hline Micromonas pusilla & $2.7 \times 10^{6}$ & $0.578 \pm 0.017$ & $660 \pm 210$ \\
\hline Bodo sp. & 290 & $0.111 \pm 0.011$ & $0.51 \pm 0.10$ \\
\hline B3 flagellate & $6.6 \times 10^{4}$ & $0.229 \pm 0.032$ & $2.40 \pm 0.29$ \\
\hline E1 flagellate & 6350 & $0.295 \pm 0.061$ & $8.16 \pm 2.07$ \\
\hline E9 flagellate & $1.4 \times 10^{5}$ & $0.115 \pm 0.003$ & $0.54 \pm 0.15$ \\
\hline E9 flagellate diluted 1:10 & $2.2 \times 10^{4}$ & $0.037 \pm 0.001$ & $0.19 \pm 0.06$ \\
\hline Scuticociliate sp. & 6550 & $0.329 \pm 0.079$ & $30.0 \pm 1.4$ \\
\hline \multicolumn{4}{|l|}{ Coos Bay water } \\
\hline 6 June 1992 & 1040 & $0.161 \pm 0.026$ & $0.81 \pm 0.10$ \\
\hline 26 July 1992 & 630 & $0.090 \pm 0.028$ & $0.27 \pm 0.08$ \\
\hline 26 July 1992 & 630 & $0.098 \pm 0.023$ & $0.27 \pm 0.08$ \\
\hline \multicolumn{4}{|l|}{ Nearshore water samples } \\
\hline 1 & 1360 & $0.016 \pm 0.003$ & $0.15 \pm 0.00$ \\
\hline 2 & 1290 & $0.021 \pm 0.001$ & $0.17 \pm 0.04$ \\
\hline 3 & 1120 & $0.016 \pm 0.004$ & $0.15 \pm 0.03$ \\
\hline 4 & 810 & $0.017 \pm 0.004$ & $0.16 \pm 0.01$ \\
\hline 5 & 540 & $0.011 \pm 0.001$ & $0.15 \pm 0.05$ \\
\hline 6 & 320 & $0.025 \pm 0.001$ & $0.17 \pm 0.01$ \\
\hline 7 & 820 & $0.006 \pm 0.001$ & $0.14 \pm 0.01$ \\
\hline \multicolumn{4}{|l|}{ Offshore water samples } \\
\hline 1 & 140 & $0.003 \pm 0.001$ & $0.022 \pm 0.009$ \\
\hline 2 & 150 & $0.003 \pm 0.001$ & $0.024 \pm 0.011$ \\
\hline 3 & 300 & $0.005 \pm 0.000$ & $0.028 \pm 0.008$ \\
\hline 4 & 120 & $0.003 \pm 0.001$ & $0.020 \pm 0.002$ \\
\hline 5 & 205 & $0.003 \pm 0.000$ & $0.020 \pm 0.013$ \\
\hline 6 & 290 & $0.006 \pm 0.001$ & $0.037 \pm 0.008$ \\
\hline
\end{tabular}

\section{Optimum sonication}

Lysozyme activity was found at acid $\mathrm{pH}$ only after protistan cells were disrupted by sonication; $\mathrm{L}_{\mathrm{ACID}}$ activity was undetectable in unsonicated samples. Maximal $\mathrm{L}_{A C I D}$ activity was observed after two $10 \mathrm{~s}$ sonication bursts; no further increase in yield of MUF was found for up to five $10 \mathrm{~s}$ bursts. For sonication periods longer than two $10 \mathrm{~s}$ bursts, we recommend the use of an ice bath around the sample during sonication to avoid an increase in sample temperature.

\section{Controls}

Two types of controls were used: boiled sonicated samples (control without active enzyme) and $0.2 \mu \mathrm{m}$ filtered unsonicated samples (control without microbes, to test for presence of extracellular digestive enzymes). The control which yielded the highest fluorescence was used to correct fluorescence values from the experimental samples. Boiled controls had lower background fluorescence than did autoclaved or microwaved samples. Use of tightly sealed containers during the boiling process reduced the variability of background fluorescence replicate values in boiled controls, probably due to evaporation. Boiled controls showed no increase in MUF fluorescence during enzyme activity assays. In general, boiled controls gave higher background fluorescence than $0.2 \mu \mathrm{m}$ filtered controls, and control fluorescence values were 10 to $20 \%$ of those of experimental samples. However, in one estuarine sample taken from a dock at Coos Bay, there was evidence for the presence of a high concentration of extracellular lysozyme in $0.2 \mu \mathrm{m}$ filtered water. The high $\mathrm{L}_{\mathrm{ACID}}$ activity (control fluorescence nearly as great as that of experimental samples) in the filtered control occurred during a coastal phytoplankton bloom, and could have been due in part to filterfeeding benthic organisms around the dock.

\section{Acid lysozyme assay results}

$\mathrm{L}_{\mathrm{ACID}}$ assays performed using aliquots of cultures of heterotrophic flagellates and a scuticociliate yielded rates of MUF production ranging from 0.037 to

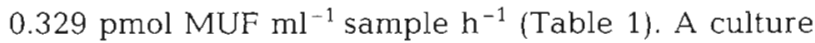




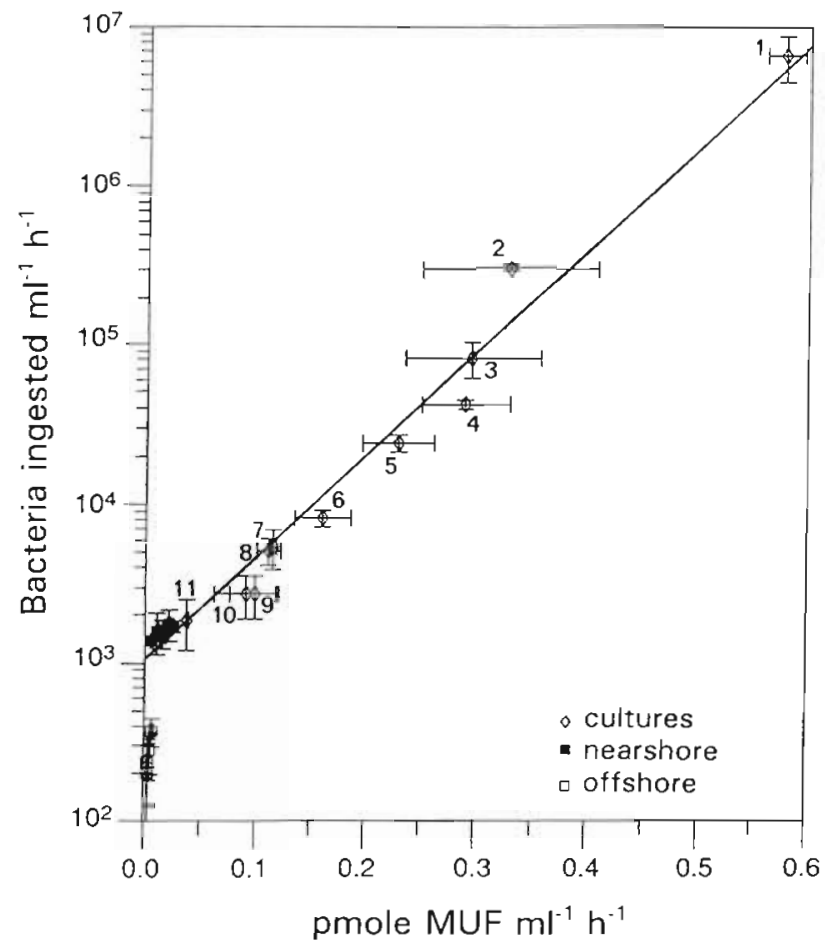

Fig. 3. Semilog plot of the relation between bacterivory $(B$, bacteria ingested $\mathrm{ml}^{-1}$ sample $\left.\mathrm{h}^{-1}\right)$, determined via short-term FLB uptake experiments, and acid lysozyme activity ( $L_{A C I D}$ pmol MUF $\mathrm{ml}^{-1}$ sample $\mathrm{h}^{-1}$ ) for all experimental analyses. Data is from monospecific isolates of bacterivorous flagellates and ciliates, mixed species assemblages of flagellates in Coos Bay estuary, and nearshore and offshore (gyre) surface seawater. Numbered data points are: (1) Paraphysomonas sp.; (2) Micromonas pusilla; (3) a scuticociliate sp.; (4) flagellate culture, E1 isolate (5) flagellate culture, B3 isolate $_{(6)}$ flagellate culture, E9 isolate; (7) Bodo parvulus; (8) E9 isolate; (9 to 11) Coos Bay surface water. Equation of the regression line (of fshore data points excluded) is: $\log B=3.0+6.4 L_{A C I D}$ $r^{2}=0.98$. See Fig. 4 for details of nearshore and offshore data

of $2.7 \times 10^{6}$ cells $\mathrm{ml}^{-1}$ of the phytoflagellate Micromonas pusilla showed the highest rate of acid lysozyme activity, $0.578 \mathrm{pmol}$ MUF $\mathrm{ml}^{-1}$ sample $\mathrm{h}^{-1}$. The average coefficient of variation for culture data was $11.5 \%$ Enzyme activity in natural water samples was lower: $0.116 \pm 0.032$ pmol MUF $\mathrm{ml}^{-1}$ sample $\mathrm{h}^{-1}$ for inshore waters of Coos Bay, $0.016 \pm 0.006 \mathrm{pmol}$ MUF $\mathrm{ml}^{-1}$ sample $\mathrm{h}^{-1}$ in nearshore waters, and $0.004 \pm 0.001$ pmol MUF ml-1 sample $h^{-1}$ in offshore waters. Average coefficients of variation for in situ sample activities were $24,3,14.3$ and $28.8 \%$ for inshore, nearshore, and offshore samples respectively.

\section{FLB uptake experiments}

A wide range of bacterial grazing rates, from 0.19 to $8.16 \times 10^{4}$ bacteria $\mathrm{ml}^{-1} \mathrm{~h}^{-1}$, was observed in cultures

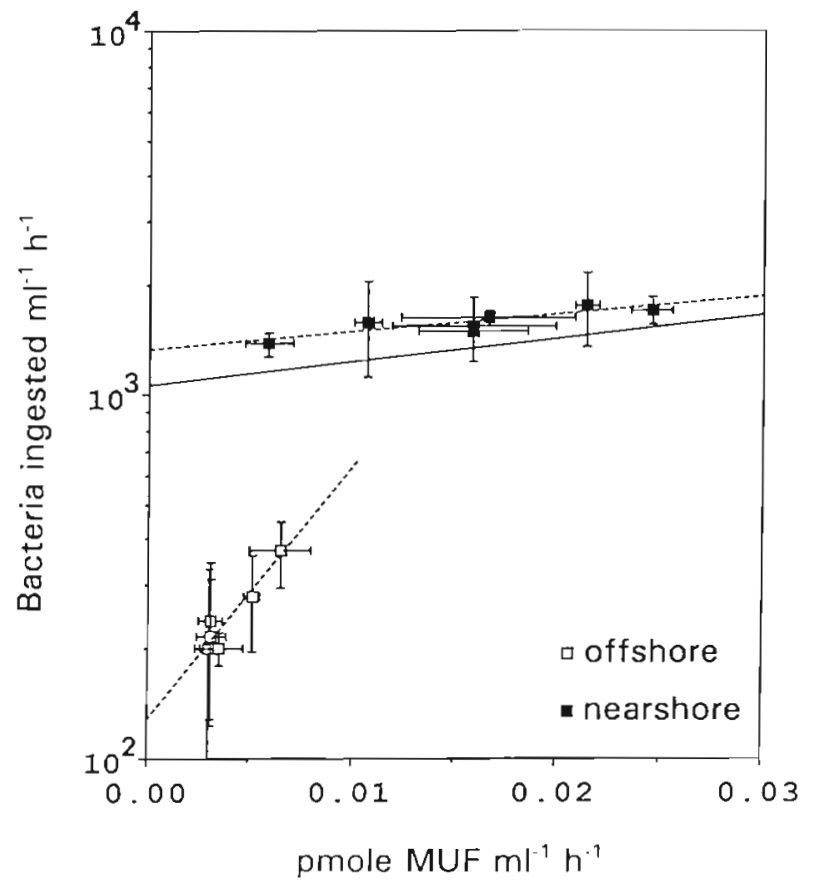

Fig. 4. Detail of Fig. 3, showing the semilog relations between bacterivory $(B)$ and acid lysozyme activity $\left(L_{A C D D}\right)$ for the nearshore and offshore data sets. Nearshore samples were taken from surface water $56 \mathrm{~km}$ from the Oregon coast, and offshore samples from surface water in the open gyre of the northeastern Pacific Ocean, $380 \mathrm{~km}$ from shore. The regression line for the nearshore samples (upper dotted line), $\log B=3.1+4.9 L_{\mathrm{ACID}}, \mathrm{r}^{2}=0.72$, is not significantly different from that of the overall regression line in Fig. 3, shown as a solid line here. However, the regression Iine for the offshore data (lower dotted line), $\log B=2.1+68 L_{\mathrm{ACID}}, \mathrm{r}^{2}=0.88$, had a

10 -fold higher slope compared to the other 2 regressions

of heterotrophic flagellates (Table 1). The scuticociliate culture consumed $30 \times 10^{4}$ bacteria $\mathrm{ml}^{-1} \mathrm{~h}^{-1}$. The highest measured rate of bacterivory, $660 \times 10^{4}$ bacteria $\mathrm{ml}^{-1} \mathrm{~h}^{-1}$, was found for Micromonas pusilla. FLB uptake by protistan assemblages in 3 samples of surface seawater collected from Coos Bay during a phytoplankton bloom indicated an average community grazing rate of $0.45 \times 10^{4}$ bacteria $\mathrm{ml}^{-1} \mathrm{~h}^{-1}$, within the range of values observed for cultures of heterotrophic flagellates. In the inshore samples, ingestion of bacteria by the ciliate assemblage was only about $5 \%$ of the ingestion of bacteria by the heterotrophic flagellate assemblage (data not shown).

Bacterivory was also estimated in more oligotrophic waters at 2 stations in the northeastern Pacific Ocean with distinctly different planktonic communities. At the offshore station, OS-1, there were $0.60( \pm 0.02) \times$ $10^{6}$ bacteria $\mathrm{ml}^{-1}, 200( \pm 70)$ heterotrophic flagellates $\mathrm{ml}^{-1}$, and $0.06 \mu \mathrm{g}$ chlorophyll $\mathrm{al}^{-1}$. Surface water at the more eutrophic nearshore station (NS-1) contained $2.8( \pm 0.3) \times 10^{6}$ bacteria $\mathrm{ml}^{-1}, 900( \pm 300)$ heterotrophic 
flagellates $\mathrm{ml}^{-1}$, and $0.8 \mu \mathrm{g}$ chlorophyll $\mathrm{a} \mathrm{l}^{-1}$. The average bacterial cell biovolume was $0.046 \pm 0.028 \mu \mathrm{m}^{3}$ in offshore waters and $0.096 \pm 0.064 \mu \mathrm{m}^{3}$ in nearshore waters. Average rates of community bacterivory were 250 bacteria $\mathrm{ml}^{-1} \mathrm{~h}^{-1}$ in offshore waters and $1600 \mathrm{bac}$ teria $\mathrm{ml}^{-1} \mathrm{~h}^{-1}$ in nearshore waters. At both stations, the ratio between abundance of bacteria and abundance of flagellates was about 3000:1. Coefficients of variation for FLB grazing rate estimates ranged from 14 to $36 \%$.

\section{Relationship between measurements by $\mathrm{L}_{\mathrm{ACID}}$ assay and FLB uptake}

Results from the 2 independent methods of quantifying bacterivory, acid lysozyme activity and FLB uptake, were significantly correlated over 4 orders of magnitude of bacterivory rates (Fig. 3). The relation between lysozyme activity, $L_{\text {ACID }}$ (pmol MUF produced $\mathrm{ml}^{-1}$ sample $\mathrm{h}^{-1}$ ), and bacterial ingestion, $B$ (bacteria cleared $\mathrm{ml}^{-1} \mathrm{~h}^{-1}$ ), was $\log B=3.0+6.4 L_{\mathrm{ACID}}, \mathrm{r}^{2}=0.98$, for combined data from experiments with monospecific cultures of bacterivorous protists and with estuarine and nearshore seawater. However, the relation between the 2 variables determined using water samples taken in open North Pacific gyre water (Fig. 4) had a 10 -fold higher slope $\left(\log B=2.1+68 L_{A C I D}, r^{2}=0.88\right)$ compared to that of the other samples.

\section{Concentrating flagellate assemblages}

As one means of obtaining higher fluorescence yields in the acid lysozyme assay performed on natural seawater samples, nanoplankton present in seawater samples were concentrated 1:10 in volume by centrifugation. $\mathrm{L}_{\mathrm{ACID}}$ activity was measured, and heterotrophic flagellates were counted, in aliquots of both concentrated and unconcentrated water samples. Results showed an average concentration factor of $4.30( \pm 0.25)$ for number of flagellates and of 4.66 ( \pm 0.23 ) for fluorescence intensity (Table 2). Centrifugation at higher speeds yielded similar flagellate recovery, but it resulted in physically damaged flagellates, as observed using epifluorescence microscopy. Concentration would be appropriate to obtain higher fluorescence yields in samples with low protist abundances and low rates of bacterivory.

\section{DISCUSSION}

The method of assessing bacterivory proposed here differs from other techniques used to estimate rates of
Table 2. Ratios of numbers of heterotrophic flagellates, and of amount of MUF fluorescence produced during acid lysozyme activity assays, in 10 -fold concentrated versus unconcentrated water samples. Values are means of triplicate determinations $\pm 1 \mathrm{SD}$

\begin{tabular}{|lcc|}
\hline Sample & Flagellate ratio & Fluorescence ratio \\
\hline Coos Bay water & $4.43 \pm 0.26$ & $4.52 \pm 0.54$ \\
Nearshore water & $4.53 \pm 0.34$ & $4.47 \pm 1.53$ \\
Offshore water & $3.95 \pm 0.98$ & $4.98 \pm 2.04$ \\
Mean value & $4.30 \pm 0.25$ & $4.66 \pm 0.23$ \\
\hline
\end{tabular}

protistan bacterivory in that it measures in vitro activity of an enzyme present in protistan food vacuoles at an instant in time, rather than an in vivo rate process determined by manipulation and incubation of living protists. The acid lysozyme assay thus is a measure of the recent past history of in situ ingestion of bacteria by protists. Other investigators (e.g. Fenchel 1975, Dolan \& Coats 1991) have estimated ingestion rates by following the time course of prey digestion in food vacuoles. We have gone a step further in this approach by quantification of activity of a digestive enzyme, acid lysozyme in this case, which hydrolyzes peptidoglycan, a structural polymer characteristic of a specific type of prey cell, i.e. bacteria. This approach is analogous to that used previously in investigations of copepod feeding behavior, in which activity of digestive enzymes in the gut was related to quantity and quality of phytoplankton prey ingested by the copepods (Hassett \& Landry 1982, Harris et al. 1986).

The fluorogenic substrate, MUF-[GlcNAc| $]_{3}$, used by us as an analogue of peptidoglycan (Yang \& Hamaguchi 1980), has several advantages with respect to other surrogate substrates which can also be used to assess lysozyme activity. Use of other substrates degraded by lysozyme, e.g. 4-MUF N-acetyl-D-glucosamine (MUF-[GlcNAc]), 4-MUF N,N'-diacetyl- $\beta$-Dchitobiose (MUF-[GlcNAc] $]_{2}$ ), p-nitrophenyl- $\beta$-glycosides, or MUF-[GlcNAc] $]_{n}$ for $n>3$, may result in strong non-lytic binding as well as cleavage at more than 1 glycosidic bond, thus complicating the reaction kinetics and data analysis. In contrast, MUF-[GlcNAc $]_{3}$ maximizes productive substrate-enzyme bindings resulting in the cleavage of the glycosidic bond with MUF, and shows simple reaction kinetics (Yang \& Hamaguchi 1980).

Food vacuole digestive enzymes of protists have been reported to show optimum activity at acid $\mathrm{pH}$ (Müller et al. 1966, Nilsson 1979, Nagata \& Kirchman 1992). In this study, we found a peak in acid lysozyme activity at pH 4.5 (Fig. 2), which is near the optimum $\mathrm{pH}, 4.9$, for activity of acid phosphatase in protist food vacuoles reported by Nagata \& Kirchman (1992). 
Running the lysozyme activity assays at $\mathrm{pH} 4.5$ thus allowed us to distinguish digestive lysozyme activity from activity of extracellular and cytoplasmic alkaline lysozymes associated with marine microbes.

The fact that unsonicated samples, as well as sonicated samples containing only bacteria, did not show significant MUF production suggested that measured $L_{\mathrm{ACID}}$ activity was contained intracellularly in protists. Relatively low fluorescence production in $0.2 \mu \mathrm{m}$ filtered seawater controls confirmed that the measured activity at acid $\mathrm{pH}$ did not result from free extracellular enzymes in the environment.

In order to obtain quantitative estimates of bacterivory, the enzyme activity data must be calibrated against independently measured rates of bacterial ingestion. We chose the FLB uptake method as one of the best methods available for calibrating the acid lysozyme assay. As discussed in the introduction, uptake of FLB by phagotrophic protists during short-term incubations has been used to determine in situ rates of clearance of bacteria by protistan communities in both marine and freshwater systems (e.g. Bloem et al. 1989, Sherr et al. 1989, Epstein \& Shiaris 1992, Simek \& Straskrabova 1992). Short-term uptake analysis of bacterivory also offers a reasonable approximation of the 'snapshot' of bacterial uptake by protists given by $L_{A C I D}$ measures.

There are potential problems with the FLB uptake approach. Phagotrophic protists may discriminate against heat-killed FLB in favor of living bacteria, in part due to motility of live bacterial cells (Nygaard \& Hessen 1990, Landry et al. 1991, Monger \& Landry 1992). Recent work in our laboratory suggests that grazing rates based on uptake of non-motile cells may underestimate actual bacterivory by 2 - to 4 -fold when the proportion of motile bacteria within the in situ assemblage is $>1$ to $10 \%$ (J. M. González, E. B. Sherr \& B. F. Sherr unpubl.). Bacterivorous protists selectively graze larger bacterial cells at faster rates than they do smaller cells (González et al. 1990b, Monger \& Landry 1991, 1992, Simek \& Chrzanowski 1992), thus size of added FLB relative to average cell size of in situ bacterioplankton can affect grazing rates. Other problems are loss of FLB from food vacuoles during fixation of protist cells (Sherr et al. 1989) and sources of error involved in the use of surrogate food particles (McManus \& Okubo 1991).

Despite the problems associated with calibrating acid lysozyme activity using the FLB uptake assay, we found a high degree of correlation between the 2 parameters over a range of nearly 4 orders of magnitude of bacterial ingestion rates $\left(1.4 \times 10^{3}\right.$ to $6.6 \times 10^{6}$ bacteria ingested $\mathrm{ml}^{-1} \mathrm{~h}^{-1}$ ) (Fig 3). The daily rates of bacterivory for Coos Bay and nearshore shelf waters based on the FLB uptake data ranged from 0.04 to $0.19 \times 10^{6}$ bacteria $\mathrm{ml}^{-1} \mathrm{~d}^{-1}$, at the low end of rates of daily bacterial ingestion reported previously (Sherr et al. 1986, Pace 1988, Sherr et al. 1989). However, Oregon coastal waters are characterized by lower standing stocks of bacteria (0.3 to $2 \times 10^{6}$ cells $\left.\mathrm{ml}^{-1}\right)$ and of phagotrophic flagellates (500 to $\left.1500 \mathrm{ml}^{-1}\right)$, and by lower temperatures $\left(6\right.$ to $12^{\circ} \mathrm{C}$ ) (M. Suzuki unpubl. data), compared to the sampling sites of earlier studies.

The slope of the relation between bacterivory and MUF production was about 10-fold higher for offshore water samples compared to the rest of the data set (Figs. $3 \& 4$ ). There are at least 2 possible explanations. The first is that bacterivory may have been underestimated for offshore protist grazers compared to cultured and nearshore protists, due to discrimination against FLB by offshore protists. The second explanation relates to differences in proportional composition of cell wall material in bacterioplankton. Suspended bacteria in the offshore samples had a smaller average cell biovolume $\left(0.046 \mu^{3}\right)$ compared to bacteria in nearshore waters $\left(0.096 \mu \mathrm{m}^{3}\right)$. Cell wall material comprises a larger proportion of total cell constituents in the 'mini' bacteria characteristic of oligotrophic seawater, in contrast to larger bacteria in more eutrophic systems (Simon \& Azam 1989). Thus the difference between the 2 slopes shown in Fig. 4 might be due to offshore bacterivorous protists requiring relatively more lysozyme to digest a unit of bacterial biomass than would nearshore protists.

If the apparent difference in digestive enzyme activity per unit of prey biomass ingested for offshore compared to nearshore flagellates is real, this may provide insights concerning trophic efficiencies at the 2 sites. González et al. (unpubl.) reported significantly longer digestion times and higher gross growth efficiencies for marine flagellates feeding on smaller, starved, compared to flagellates feeding on larger, growing, bacterial cells. The idea that offshore protists feeding on smaller, less abundant bacterial cells digest their prey more efficiently compared to nearshore protists feeding on larger, more abundant bacteria fits the 'reactor' theory of digestion (Penry \& Jumars 1987, Jumars et al. 1989), in which food-limited animals digest their prey more completely than do animals feeding under conditions of high food abundance. Variability in digestive processes of in situ phagotrophic protists may be a fruitful topic for future investigation.

The results of our study additionally demonstrate that the volumetric rate of bacterial consumption (bacteria ingested $\mathrm{ml}^{-1} \mathrm{~h}^{-1}$ ) is not necessarily tightly coupled to abundance of bacterivores. Based on the data shown in Table 1, in natural water samples cellspecific rates of bacterivory varied from 1 to 5 bacteria flagellate ${ }^{-1} \mathrm{~h}^{-1}$, and per cell rates of $\mathrm{L}_{\mathrm{ACID}}$ activity ranged from 12 to $150 \times 10^{-18} \mathrm{~mol}$ MUF flagellate ${ }^{-1} \mathrm{~h}^{-1}$. 
We also observed that in laboratory culture, log growth phase bacterivorous protists had high cell-specific $\mathrm{L}_{\mathrm{ACID}}$ activity, while stationary phase bacterivores had very low cell-specific rates of activity. Thus $L_{A C I D}$ activity appears to be a more accurate and reliable indicator of bacterial grazing mortality than standing stock of bacterivores would be.

In order to improve the sensitivity of the assay in natural waters, we tried concentration of heterotrophic protists in water samples via centrifugation. Bloem et al. (1986) concentrated heterotrophic protists by centrifugation at $600 \times g$. We empirically obtained higher recovery, both in numbers of protists and in enzyme activity, by increasing the centrifugal speed to $2000 \times \mathrm{g}$. Faster speeds did not improve protist recovery and also resulted in apparently damaged flagellates. The recovery efficiency of a 1:10 concentration was on the order of 40 to $45 \%$ for heterotrophic flagellates, and thus resulted in 4 -fold higher rates of production of MUF during the assay (Table 2).

The advantages of the acid lysozyme activity method for estimation of in situ rates of bacterivory are that the assay does not involve incubation of live samples; it is a 'snapshot' measure of recent bacterial ingestion by in situ protists; it does not require extensive microscopic enumeration; and multiple samples can be processed fairly quickly. The assay can be used to obtain estimates of relative bacterivory in both cultures and natural samples. In using the method with microbial cultures, one should avoid high concentrations of fluorescent compounds such as yeast extract. It is important to include both killed (boiled) sonicated controls and controls of $0.2 \mu \mathrm{m}$ filtered unsonicated samples with each lysozyme assay to check for background fluoresence and for free lysozyme activity at acid $\mathrm{pH}$

In order to use acid lysozyme activity as a quantitative measure of bacterivory, it is necessary to calibrate MUF production rates with an independent assay of bacterivory for each system studied. We used the FLB uptake technique; other methods might also be used. Calibration of the acid lysozyme activity method needs further attention.

The $\mathrm{L}_{\mathrm{ACID}}$ assay is the first of a possible family of methods based on the general approach of measurement of activity of standing stocks of digestive enzymes in protist food vacuoles as an indicator of protist grazing rates in situ. In this case, we designed a method specifically to quantify rates of bacterivory. J. Vrba \& K. Simek (unpubl.) have recently found that a high-affinity $\mathrm{N}$-acetylglucosaminidase was associated with freshwater bacterivorous flagellates, using the substrate MUF-[GlcNAc], and suggested that activity of this enzyme could also be used as an indicator of bacterivory. Activity of other types of hydrolytic enzymes, e.g. phosphatases, peptidases, or glucosi- dases, at acid pH might be assayed to determine overall rates of protist grazing, by substituting appropriate fluorochrome-linked analogue substrates (Chróst 1991. Hoppe 1991) in place of the peptidoglycan analogue, MUF-[GlcNAc] $]_{3}$ used here.

Acknowledgements. We thank Kraig Slack for chlorophyll a data for the oceanographic stations, Drs David Caron and Lynda Shapiro for providing cultures of bacterivorous flagellates and phytoplankton, and Drs Steve Newell, Jarda Vrba and Karel Simek, as well as 3 anonymous reviewers, for their comments on the first draft of the manuscript. This work was supported by NSF Grants OCE-9096215 and OCE-9116301 to B.F.S. and E.B.S, by DOE Grant DE-FG0692ER61423 to B.F.S. and E.B.S., and by a postdoctoral fellowship from the Spanish Ministry of Education and Science to J.M.G.

\section{LITERATURE CITED}

Azam, F., Fenchel, T., Field, J. G., Gray, J. S., Meyer-Reil, L. A., Thingstad, F. (1983). The ecological role of watercolumn microbes in the sea. Mar. Ecol. Prog. Ser. 10: $257-263$

Bloem, J., Bar-Gilissen, M.-J. B., Cappenberg, T E. (1986). Fixation, counting and manipulation of heterotrophic nanoflagellates. Appl. environ. Microbiol. 52: 1266-1272

Bloem, J., Ellenbroek, F. M., Bar-Gilissen, M. B., Cappenberg, T. E. (1989). Protozoan grazing and bacterial production in stratified Lake Vechten estimated with fluorescently labeled bacteria and thymidine incorporation. Appl. environ. Microbiol. 55: 1787-1795

Chróst, R. J. (1991). Environmental control of the synthesis and activity of aquatic microbial ectoenzymes. In: Chróst, R. J. (ed.) Microbial enzymes in aquatic environments. Springer-Verlag, New York, p. 29-59

Cole, J. J., Findlay, S. Pace, M. L. (1988). Bacterial production in fresh and saltwater ecosystem: a cross-system overview. Mar. Ecol. Prog. Ser. 43: 1-10

Dolan, J. R., Coats, D. W. (1991). Preliminary prey digestion in a predacious estuarine ciliate and the use of digestion data to estimate ingestion. Limnol. Oceanogr. 36: 558-565

Epstein, S. S., Shiaris, M. P. (1992). Size-selective grazing of coastal bacterioplankton by natural assemblages of pigmented flagellates, colorless flagellates, and ciliates. Microb. Ecol. 23: 211-225

Fenchel, T. (1975). The quantitative importance of the benthic microfauna of the arctic tundra pond. Hydrobiology 46 $445-464$

Ferguson, R. L., Buckley, E. N., Palumbo, A. V. (1984) Response of marine bacterioplankton to differential filtration and confinement. Appl. environ. Microbiol. 47:49-55

González, J. M., lriberri, J., Egea, L., Barcina, I. (1990a) Differential rates of digestion of bacteria by freshwater and marine phagotrophic protozoa. Appl. environ. Microbiol. 56: 1851-1857

González, J. M., Sherr, E. B., Sherr, B. F. (1990b). Size-selective grazing on bacteria by natural assemblages of estuarine flagellates and ciliates. Appl. environ. Microbiol. 56 $583-589$

Harris, R. P., Samain, J.-F., Moal, J., Martin-Jezequel, V. Poulet, S. A. (1986). Effects of algal diet on digestive enzyme activity in Calanus helgolandicus. Mar. Biol. 90: $353-361$ 
Harrison, P. J., Waters, R. E., Taylor, F. J. R. (1980). A broad spectrum artificial seawater medium for coastal and open ocean phytoplankton. J. Phycol. 16: 28-35

Hassett, R. P., Landry, M. R. (1982). Digestive carbohydrase activities in individual marine copepods. Mar. Biol. Lett. 3 211-221

Hobbie, J. E., Daley, R. J, Jasper, S. (1977). Use of nuclepore filters for counting bacteria by fluorescence microscopy. Appl. environ. Microbiol. 33: 1225-1228

Hoppe, H. -G. (1983). Significance of exoenzymatic activities in the ecology of brackish water: measurements by means of methylumbelliferyl-substrates. Mar. Ecol. Prog. Ser. 11: 299-308

Hoppe, H.-G. (1991). Microbial extracellular enzyme activity: a new key parameterin aquatic ecology. In: Chróst, R. J. (ed.) Microbial enzymes in aquatic environments. Springer-Verlag, New York, p. 60-83

Jumars, P. A., Penry, D. L., Baross, J. A., Perry, M. J., Frost, B. W. (1989). Closing the microbial loop: dissolved carbon pathway to heterotrophic bacteria from incomplete ingestion, digestion and adsorption in animals. Deep Sea Res. 36: $483-495$

Landry, M. R., Haas, L. W., Fagerness, V. L. (1984). Dynamics of microbial plankton communities: experiments in Kaneohe Bay, Hawaii. Mar. Ecol. Prog. Ser 16: 127-133

Landry, M. R., Lehnerfoumier, J. M., Sundstrom, J. A., Fagerness, V. L., Selph, K. E. (1991). Discrimination between living and heat-killed prey by a marine zooflagellate, Paraphysomonas vestita (Stokes). J. exp. mar. Biol. Ecol. 146: 139-152

Marrasé, C., Lim, E. L., Caron, D. A. (1992). Seasonal and daily changes in bacterivory in a coastal plankton community. Mar. Ecol. Prog. Ser. 82: 281-289

McManus, G. B., Fuhrman, J. A. (1988). Control of marine bacterioplankton populations: measurement and significance of grazing. Hydrobiologia 159: 51-62

McManus, G. B., Okubo, A. \{1991\}. On the use of surrogate food particles to measure protistan ingestion. Limnol. Oceanogr. 36: 613-617

Monger, B. C., Landry, M. R. (1991). Prey-size dependency of grazing by free-living marine flagellates. Mar. Ecol. Prog. Ser 74:239-248

Monger, B. C., Landry, M. R. (1992). Size-selective grazing by heterotrophic nanoflagellates: an analysis using livestained bacteria and dual-bean flow cytometry. Arch. Hydrobiol. Beih. Ergebn. Limnol. 37: 173-185

Müller, M., Boudhuin, P., de Duve, C. (1966). Lysosomes in Tetrahymena pyriformis. I. Some properties and lysosomal localization of acid hydrolases. J. Cell. Physiol. 68: $165-176$

Münster, U. (1991), Extracellular enzyme activity in eutrophic and polyhumic lakes. In: Chróst, R. J. (ed.) Microbial enzymes in aquatic environments. Springer-Verlag, New York, p. 96-122

Nagata, T. Kirchman, D. L. (1992). Release of macromolecular organic complexes by heterotrophic marine flagellates. Mar. Ecol. Prog. Ser. 83: 233-240

Nilsson., J R. (1979). Phagotrophy in Tetrahymena. In: Levandowsky, M., Hunter, S. H. (eds.) Biochemistry and physiology of protozoa, Vol. 2, 2nd edn. Academic Press, New York, p. 339-379

Nygaard, K. Hessen, D. O. (1990). Use of ${ }^{14} \mathrm{C}$-protein-labelled bacteria for estimating clearance rates by heterotrophic and mixotrophic flagellates. Mar. Ecol. Prog. Ser. 68: $7-14$

This article was presented by D. A. Caron, Woods Hole, Massachusetts, USA
Pace, M. L. (1988). Bacterial mortality and the fate of bacterial production. Hydrobiologia 159: 41-49

Pace, M. L., Bailiff, M. D. (1987). Evaluation of a fluorescent microsphere technique for measuring grazing rates of phagotrophic microorganisms. Mar. Ecol. Prog. Ser. 40: 185-193

Penry, D. L., Jumars, P. A. (1987). Modeling animal guts as chemical reactors. Am. Nat. 129: 69-96

Pomeroy, L. R. (1974). The ocean's food web, a changing paradigm. BioSci. 24: 499-504

Porter, K. G., Feig, Y. S. (1980). The use of DAPI for identifying and counting aquatic microflora. Limnol. Oceanogr. 25: $94.3-948$

Sherr, B. F., Sherr, E. B., Andrew, T. L., Fallon, R. D., Newell, S. Y (1986). Trophic interactions between heterotrophic protozoa and bacterioplankton in estuarine water analyzed with selective metabolic inhibitors. Mar. Ecol. Prog. Ser. 32: 169-179

Sherr, B. F., Sherr, E. B. Fallon, R. D. (1987). Use of monodispersed, fluorescently labeled bacteria to estimate in situ protozoan bacteriovory. Appl. environ. Microbiol. 53: 958-965

Sherr, B. F., Sherr, E. B., McDaniel, J. (1992). Effect of protistan grazing on the frequency of dividing cells in bacterioplankton assemblages. Appl. environ. Microbiol. 58: $2381-2385$

Sherr, B. F., Sherr, E. B., Pedros-Alio, C. (1989). Simultaneous measurement of bacterioplankton production and protozoan bacterivory in estuarine water. Mar. Ecol. Prog. Ser. 54: 209-219

Simek, K. Chrzanowski, T. H. (1992). Direct and indirect evidence of size-selective grazing on pelagic bacteria by freshwater nanoflagellates. Appl. environ. Microbiol. 58: 3715-3720

Simek, K., Straskrabova, V (1992). Bacterioplankton production and protozoan bacterivory in a mesotrophic reservoir. J. Plankton Res. 14: 773-788

Simon, M., Azam, F. (1989). Protein content and protein synthesis rates of planktonic marine bacteria. Mar. Ecol. Prog. Ser. 51: 201-213

Sleigh, M. (1989). Protozoa and other protists. Edward Arnold, New York

Sokal, R. R., Rohlf, F. J. (1981). Biometry, 2nd edn. W. H. Freeman \& Co. New York

Somville, M. (1984). Measurements and study of substrate specificity of exoglucosidase activity in eutrophic water. Appl. environ. Microbiol. 48: 11.81-1185

Stryer, M. (1981). Biochemistry, 2nd edn. W. H. Freeman \& Co., San Francisco

Taylor, G. T., Pace, M. E. (1987). Validity of eukaryote inhibitors for assessing production and grazing mortality of marine bacterioplankton. Appl. environ. Microbiol. 53: $119-128$

Wikner, J., Andersson, A., Normark, S., Hagstron, A. (1986) Use of genetically marked minicells as a probe in measurement of predation on bacteria in aquatic environments. Appl. environ. Microbiol. 52: 4-8

Wright, R. T., Coffin, R. B. (1984). Measuring microzooplankton grazing on planktonic marine bacteria by its impact on bacterial production. Microb. Ecol. 10: 137-149

Yang, Y., Hamaguchi, K. (1980). Hydrolysis of 4-methylumbelliferyl $\mathrm{N}$-acetyl-chitotrioside catalyzed by hen and turkey lysozymes: $\mathrm{pH}$ dependence of the kinetic constants. J. Biochem. 87. 1003-1014 